\title{
基于专业竞赛加快高职院校 “金课” 建设的研究
}

\section{Research on Speeding Up the Construction of "Golden Course" in Higher Vocational Colleges Based on Professional Competition}

\author{
吴晓丽 于洁 \\ Xiaoli $\mathrm{Wu}$ Jie $\mathrm{Yu}$ \\ 内蒙古农业大学职业技术学院 中国·内蒙古 包头 014109
}

Vocational and Technical College of Inner Mongolia Agricultural University, Baotou, Inner Mongolia, 014109, China

摘 要: “金课”建设背景下，本研究团队研究高职院校“金课”建设和应用情况，初步探明“金棵”在高职院校的推进 尤为艰难。针对教育部 “金课”建设的具体任务和措施要求，论文指出高职院校要借力于专业竞赛，加速高职院校 “金课” 建设。以内蒙古农业大学职业技术学院为例构建 “以赛促改”的教学体系, 加快《建设工程项目管理》课程 “金课”建设进度, 探索提升高职院校“金课”建设质量的新途径。

\begin{abstract}
Under the background of "golden course", this research team has studied the construction and application of "golden course" in Higher Vocational Colleges, it is difficult to promote the "golden course" in Higher Vocational Colleges. Specific tasks and measures for the construction of "golden course" of the Ministry of Education, this paper points out that higher vocational colleges should rely on professional competition. Take Vocational and Technical College of Inner Mongolia Agricultural University as an example to construct the teaching system of "promoting reform by competition", to speed up the construction progress of "golden course" in the course of "construction project management", exploring a new way to improve the quality of "golden course" construction in Higher Vocational Colleges.
\end{abstract}

关键词：高职院校；金课；专业竞赛；以赛促改

Keywords : higher vocational college; golden course; professional competition; promoting reform by competition

基金项目：内蒙古自治区教育科学 “十三五”规划课题——内蒙古高职院校《建设工程项目管理》课程金课建设研究” （NZJGH2019128）；内蒙古农业大学职业技术学院 2019 年院级教育教学改革研究重大项目一一基于产教协同发展的工程 管理类专业群“六同、五化、四高”培养模式探究（201911YZDA10）

DOI: $10.36012 /$ sde.v2i11.2305

\section{1 问题的提出}

2019 年 4 月，教育部吹响了“金课” 建设的号角，全 国掀起“金课” 建设的浪潮 ${ }^{[1]}$ 。目前全国高校所有教师的课 程建设理想和目标已转向建设“金课”。纵观“金课” 研究 及成果，研究者对高校“金课”建设领域进行的探索与开发 已取得一定的成就，但是，不同高校的校情和学情不同，尽 管“金课” 给高等教育改革指明了新方向 然而高职院校“金
课” 建设研讨与建设成果鲜有报道。“金课”在高职院校落 地生根存在许多水土不服的问题，如教师备课习惯改变难、 学生线上学习流于形式等问题极大阻碍了高职院校“金课” 建设步入正轨的进度。所以, 高职院校必须结合学校实际情 况和不同课程的特点进行“金课”研讨与建设。

\section{2 高职院校“金课”建设推进的对策} 高职院校应以专业竞赛为契机，促进高校教师队伍建

【作者简介】吴晓丽（1988 ），女，甘肃张掖人，讲师，从事职业教育改革与管理研究。 
设 ${ }^{[2]}$; 以指导学生参赛为载体, 促进高职院校教师适应所教 课程“金课”建设的课改思路; 论选拔优秀参赛选手为导向， 促进高职院校学生适应“金课”的学习模式。这是高职院校 实施“金课”建设落地战略的新途径，其归根结底也是为高 职院校教学改革和社会发展服务。本研究认为高职院校应以 建设“金课”为目的, 建立“以赛促教”的教学模式, 实现 教学竞赛常规化, “以赛促改” 常态化 ${ }^{[3]}$ 。

\section{3 “以赛促改” 在高职院校“金课” 课程建 设中的实践探索}

本研究以内蒙古农业大学职业技术学院建筑工程专业 借助专业比赛推进《建设工程项目管理》课程“金课”建设 落地为例进行研究。

经过文献阅读和参赛经验分析论证得出高职院校实现

“以赛促改”必须把握好比赛四要素, 即比赛项目、参赛学生、 指导老师、参赛院校。高职院校“金课”落地要借力于比赛 就必须非常重视比赛四要素, 注重解析比赛四要素与“金课” 在校内推进之间的复杂关系，并针对四要素的具体问题进行 逐项整改，才能为《建设工程项目管理》“金课”建设借力 发挥作用。

\section{1 提高参赛项目的甄选标准}

高职院校学生参加的竞赛项目必须具备以下要求。第 一，专业竞赛项目必须与高职院校相关专业教学计划相符 合。第二, 竞赛的结果必须具有较高的社会认同度 ${ }^{[4]}$, 如此 才能引起学生关注, 学生之间形成学习竞争态势, 学生就会 从被动学习转向线上线下主动学习。第三, 竞赛必须在本校 专业教师和企业技术专家联合培训的基础上进行 ${ }^{[4]}$, 联合培 训的竞赛不仅能提高教师的教学水平，拓展教师的教学内 容, 而且能减轻教师指导比赛的压力, 学生将所学理论知识 与实践结合起来，提高学习效率。第四，专业竞赛必须将赛 前优化培训与赛后教学统一安排, 高度整合赛前、赛后培训 的比赛不仅可以提高参赛生的就业率, 而且可以提高比赛自 身的价值, 吸引更多院校参赛。根据课程需要及内蒙古农业 大学职业技术学院《建设工程项目管理》学生的实际情况， 本研究优化篮选出国家、企业认同度较高, 具备教学价值且 与学情同步的专业竞赛，具体如下: 全国大学生结构设计大 赛，中国梦绿色建筑创意设计大赛，全国 BIM 大赛，全国
结构模型大赛，全国高等院校 BIM 电子招投标大赛，全国 高等院校 BIM 应用技能大赛, 全国高校 BIM 毕业设计大赛, 全国 BIM 建模大赛。

\section{2 多角度选择参赛学生}

第一，参赛选手选拔原则为将已有教学资源效益发挥 到最大。内蒙古农大学职业技术学院土木工程专业《建设工 程项目管理》代课教师施工经验丰富，实行学徒模式培养选 拔参赛选手 ;管理与造价专业已建有“张燕斌创新工作室” 和校内外合作培训平台，该专业借助创新工作室和合作培训 平台培养选拔参赛选手。(1)施工技术专业《建设工程项目管 理》教师担任师傅, 选拔大一、大二学生中优秀学生为徒弟, 师徒团队作为专业竞赛的参赛团队。师傅制订培养计划，利 用参与建设项目亲自带徒，提高徒弟的理论知识水平与实践 技能。根据历年全国大学生结构设计大赛、中国梦绿色建筑 创意设计大赛、全国结构模型大赛、全国高校 BIM 毕业设 计大赛、全国 BIM 建模大赛的时间打好基础。(2)工程管理 与造价专业主要参加全国 BIM 大赛, 大赛科目针对 BIM 系 列软件应用。工程管理与造价专业《建设工程项目管理》教 师借助“张燕斌工作室”与合作培训平台的软硬件设备对预 备参赛学生做培训和指导，指导老师通过每周的活动以及教 师对大赛基础知识点的授课情况，掌握学生的整体水平，到 固定时间进行参赛选手选拔。

第二, 借助社团补充参赛生源。《建设工程项目管理》 专业教师组建竞赛社团，社团成员选拔通过学生自主报名、 定期考核的方式进行 ${ }^{[5]}$, 选取学习兴趣浓、自主学习意识强、 成绩优胜的高质量学生成为社团成员。社团负责教师每周在 指定平台上发布社团成员自主学习任务，并利用业余时间集 中线下授课。通过社团活动，专业教师可以及时掌握学生的 整体水平, 了解混合式教学方式存在的问题, 帮助学生尽快 适应“金课” 学习模式。参赛成员以大赛大于 $2 ： 1$ 的比例 进行选拔，这样利于“金课”模式在学生中的推广，从而达 到“ 以赛促改”的目的。

第三，储备选手要注重两个环节：(1)日常教学；(2)校 园专业竞赛 ${ }^{[6]}$ 。专业课教师在上课期间应有意识地挖掘、培 养专业竞赛选手。教研室应每年至少组织一次专业竞赛，储 备专业竞赛选手。

第四，参赛选手优选。备赛时间紧、模拟竞赛练习题 
量大、训练强度高是参赛选手赛前培训的典型特点。根据赛 前训练观察和测试学生心理素质, 优选出在赛事中处变不惊 且应激性反应能力强的选手。

通过以上四步, 争取选拔出优秀的参赛学生, 同时将 线上自主学习方法在学生之间推广。

\section{3 严格要求指导老师}

第一，教师优化篩选竞赛项目。内蒙古农业大学职业 技术学院《建设工程项目管理》“金课”建设团队根据任务 分工, 指定专业教师为学生优化篮选专业竞赛项目, 并集中 在大一下半学期进行各种形式的宣讲, 通过展示往届获奖作 品、教学成果, 让学生更清晰地了解赛事赛程及内容。

第二，指导专业竞赛教师以“金课”建设的教学重点 覆盖专业竞赛考查知识点。内蒙古农业大学职业技术学院 《建设工程项目管理》“金课”建设团队确定参赛项目和人员 后, 指导团队的教师经开会研讨, 将每个科目教学重点在教 学计划范围内向专业竞赛倾斜。本研究团队教师尝试课后测 试 双线并行 ${ }^{[7] ”}$ 措施, 即参赛学生的测试以比赛项目为主, 通过比赛项目强化课堂教学重点内容; 指导教师通过整合多 门课程的教学内容制定一个整体项目, 以项目驱动比赛、课 程衔接。

第三, 大赛考点解析要在内蒙古农业大学职业技术学院 《建设工程项目管理》“金课”建设教师日常授课的过程当中 贯穿并融入日常授课环节, 通过教学学生达到参赛标准, 通 过参赛学生将理论知识转化为实践成果，进而达到“似赛促 改”的目的。

第四，必须保证指导老师的学科专业竞赛时间完善。由 于课堂教学时间有限, 本研究团队由施工技术专业《建设工 程项目管理》教师担任师傅, 充分运用课余时间带领参赛学 生走进建设项目设计、施工现场, 由工程管理与造价专业《建 设工程项目管理》教师带领参赛学生进入“工作室”, 通过 建设项目现场观摩和实操环节与“创新工作室” 平台继续项 目实践。指导教师项目带徒和“工作室” 指导学生两种模式 不仅提供给学生实践平台，更会结合学生参加比赛、“金课” 建设的需要, 方向明确地开展探索性教学, 最大限度地发挥 学院已有资源的作用，给学生提供学习、比赛的支持。

第五, 明确赛前练习方案。以内蒙古农业大学职业技术 学院为例，指导老师赛前练习方案细分为两个方面：一是阶
段性训练方案，二是制定周课表。指导教师会在阶段性训练 方案中明确假期培训、比赛基础夯实、赛前冲刺三个阶段的 训练内容，并依据训练内容制定教师答疑授课的周课表。周 课表会结合参赛选手不同阶段备赛实际进展进行调整。“前 车之鉴, 引以为鉴”，指导教师将以往大赛中参赛学生得分 极少的考点搜集概括，在阶段性训练时反复训练。竞赛准备 时教师会坚持任务导向法推进“金课”课程内容的进行，同 时夯实参赛学生的基础。

第六，指导教师角色多重。内蒙古农业大学职业技术 学院指导竞赛的老师必须是“金课”建设课题组的教师，学 院鼓励指导教师亲临大赛现场观摩并获得直观经验来更好 地指导本校学生参赛和推进“金课”在学院落地。

第七, 赛后总结及经验推广。比赛结束后要求指导专 业竞赛的教师归纳经验形成报告，参赛教研室讨论专业大赛 在“金课”建设过程中的作用和经验并在专业间交流和推广， 真正做到以赛促学、以赛促改。

\section{4 参赛院校的支持是关键}

第一, 高职院校鼓励教师指导学生参加专业竞赛推进 “金课”建设。内蒙古农业大学职业技术学院通过教师绩效 考核时，给予指导学生参加专业竞赛获奖的老师加分、给不 同获奖级别的“优秀指导老师”发放奖金两种方式，鼓励教 师指导学生参加专业比赛。学院以比赛提升大学生课堂参与 度，推行由学生自主完成大作业、综合实训作业、综合设计 作业等方式作为“金课”考核方式。

第二，高职院校支持教师教育理念的更新。“以赛促改” 的教学模式下, 要让教师在现代教育环境中充分发挥引导者 作用，必须不断更新职业院校教师的教育、教学理念。内蒙 古农业大学职业技术学院采取以下措施更新教师的教育理 念：(1)教师培训。学院统筹安排全院在职教师参加各个专业 的培训，让教师在培训中把握国家职业教育面临的机遇和挑 战, 以及职业教育改革的动向，并在学院日常教育、教学中 积极传播和实施国家职业教育改革的新方针、新政策。(2)教 师间的交流与合作。学院派不同年龄阶段、不同学院、不同 专业的教师在学院承办或者学校参加的会议、培训、学习活 动，活动结束后由参会人在学校相关专业教师之间进行交流 与探讨，通过教师互相学习提升各自能力，更新彼此的教育 理念。(3)教育理念的更新作为教师绩效考核的依据。内蒙古 
农业大学职业技术学院构建并运行有效的绩效考核体系, 将 教育理念的更新作为评定教师综合素养的主要内容之一。

第三, 高职院校各个专业体系要积极构建学生参与专 业竞赛的有效机制, 有了更多的学生参与, 这样的竞赛体制 对“金课”的实施才更有实际意义。内蒙古农业大学职业技 术学院建立以下有效机制：(1)将参与专业竞赛纳入学生的综 合能力考核之中, 让学生意识到参赛与学习、参赛与实践同 等重要。(2)建立积极有效的参赛激励体制, 如综合成绩计算 时给予参赛的学生加小学分；评定三好学生、优秀班干部、 优秀毕业生、专科升本科、本科生推荐免试研究生时参赛、 获奖作为重要加分依据的方式, 鼓励更多的学生进入专业竞 赛社团，积极地适应“金课”学习方式。

第四，专业竞赛应在高职院校人才培养方案中体现。 内蒙古农业大学职业技术学院《建设工程项目管理》“金课” 建设团队在制订人才培养方案时, 充分考虑大赛项目, 课程 覆盖所有比赛项目，注重比赛项目内容的日常教学。

第五，专业竞赛需要专业人员指导。内蒙古农业大学 职业技术学院为《建设工程项目管理》“金课”建设团队指 导的参赛学生, 聘请建筑工程企业专家、技术骨干来校指导 参赛学生, 或者学院为学生提供机会走进企业, 学生通过顶 岗实习来加强练习的同时学习提升比赛效率的工艺方案。

第六, 加强教师队伍建设 ${ }^{[8]}$ 。内蒙古农业大学职业技术 学院结合《建设工程项目管理》“金课”建设的实际情况， 积极组织教师参与专业竞赛的学习交流、“金课”建设的专 业培训和教师深入企业进修等活动强化教师自身实践能力， 以此保证教师给学生实施更加专业的教学指导 确保“ 金课” 建设过程中建筑工程专业课程教学整体质量的提高。

第七, 高职院校充分挖掘教学资源并对教学资源进行 精细化管理，是推进专业竞赛从而促进“金课”建设的一 种新理念，本质是对“金课” 的战略和目标进行分解、细 化和落实 ${ }^{[9]}$ 。内蒙古农业大学职业技术学院全面推进校内 实训基地精化建设, 并在校企深度融合的基础上通过校企 合作方式搭建精细化实训平台, 为学生参加比赛和“金课” 教学活动提供充足的硬件基础, 让每一个学生都能获得参
与实训的机会。

\section{4 结语}

专业竞赛可以将指导教师和参赛学生的专业水平迅速 提升，但专业竞赛不是高职院校“金课”建设通向成功的捷 径。高职院校教师若想借助专业竞赛建设“金课”，必须严 格按照“金课”建设标准、体系开展“以赛促改”的教学活 动。“金课” 建设团队教师通过专业竞赛严格约束自己勤恳 付出, 扎实参赛学生的基础知识, 引导学生在参赛过程中自 主学习、勤于动手、善于动脑, 灵活运用所学的知识, 做到 “以赛促改”成果的生产精益求精。“金课”建设教师在实践 教学过程中应用“以赛促改”的成果举一反三，不断提升自 身的教学水平，才能使指导的参赛团队在专业竞赛中脱颖而 出, 达到“以课促赛, 以赛促改”的目的。

\section{参考文献}

[1] 王运武,黄荣怀,彭梓涵, 等.打造新时代中国“金课”培养“卓 越拔尖” 人才 $[\mathrm{J}]$. 中国医学教育技术 ,2019,33(4):379-384.

[2] 夏洁颖, 刘捷, 刘洋, 等 . 高职院校“以赛促教、以赛促学” 教学模式的探索一以设计构成课程为例 [J]. 吉林农业科技学 院学报 ,2019,28(1):90-93.

[3] 谈仁娟, 梅璐璐, 张秀华.“以赛促教、教赛互动”的创新人 才培养模式探究 [J]. 中外企业家, 2020(5):164.

[4] 谭玲.“以赛促学” 教学模式下高职院校会计专业竞赛体系的 构建意义及对策探讨 [J]. 经济师 ,2020(2):172-173.

[5] 陈佶. 高职院校“以赛促教、以赛促学” 人才培养模式研究 [J]. 船舶职业教育 ,2019,7(1):24-26.

[6] 莫玉鹤.“以赛促学、以赛促教、以赛促训”技能大赛模式的 构建一以恩施职业技术学院旅游管理专业为例 [J]. 旅游纵览 (下半月 ),2019(2):215.

[7] 娄建玮.潍坊职业学院: 以省科创大赛为抓手, 走出创新创业 教育特色之路 [J]. 山东教育 ( 高教 ),2020(Z1):30-32.

[8] 张润彬, 于海峰, 赵虹. 建设德能并优的“双师型”教师队伍 研究 [J]. 职业技术, 2020,19(1):95-100.

[9] 车延年, 宫恩龙. 精细化管理视阈下高职院校专业管理 : 内涵、 困境与路径 [J]. 职业技术教育 ,2020,41(7):26-32. 